Relations industrielles

Industrial Relations

\title{
Cultures in Collision : U.S. Corporate Policy and Canadian Subsidiaries, by Arthur Elliott Carlisle. Ann Arbor : University of Michigan, 1967, 162 pp.
}

\section{Joan Sichel}

Volume 25, numéro 2, 1970

URI : https://id.erudit.org/iderudit/028137ar

DOI : https://doi.org/10.7202/028137ar

Aller au sommaire du numéro

Éditeur(s)

Département des relations industrielles de l'Université Laval

ISSN

0034-379X (imprimé)

1703-8138 (numérique)

Découvrir la revue

Citer ce compte rendu

Sichel, J. (1970). Compte rendu de [Cultures in Collision : U.S. Corporate Policy and Canadian Subsidiaries, by Arthur Elliott Carlisle. Ann Arbor : University of Michigan, 1967, 162 pp.] Relations industrielles / Industrial Relations, 25(2),

381-382. https://doi.org/10.7202/028137ar

Tous droits réservés @ Département des relations industrielles de l'Université Laval, 1970
Ce document est protégé par la loi sur le droit d'auteur. L’utilisation des services d’Érudit (y compris la reproduction) est assujettie à sa politique d'utilisation que vous pouvez consulter en ligne.

https://apropos.erudit.org/fr/usagers/politique-dutilisation/ 
Cultures in Collision : U.S. Corporate Policy and Canadian Subsidiaries, by Arthur Elliott Carlisle. Ann Arbor: University of Michigan, 1967, $162 \mathrm{pp}$.

This study purports to «identify some of the effects of cultural differences on management and industrial relations policies and practices of U.S. - controlled firms operating in the different cultural and lingual setting of Quebec, and the different cultural setting of Ontario 》. (p. vii) This study was originally the author's doctoral dissertation at the University of Michigan, 1966.

The research goals are specified: « a) to identify differences in attitudes of French Canadian supervisors as compared to those of their English Canadian counterparts, b) to determine the effect of differences in French Canadian, English Canadian and U.S. institutions on operations of U.S. corporations, and c) to determine whether U.S. companies follow a systemmatic procedure in developing or modifying managerial and industrial relations policies and practices for application in English and French Canada, and, if so, whether these adaptations are made at the corporate or at the operational level ». (p. 129).

The research procedures consisted of a questionnaire, followed up by a series of interviews. These inquiries were put to American, English and French Canadian managerial personnel of eleven companies (with the exception of HydroQuebec and Aluminum Ltd. are American controlled) who had managerial experience in various locations, enabling them to make comparisons and judgements by virtue of their different experiences.

The research goals are stated in Appendix $I$, and the questionnaires in Appendix II. Whenever possible, the replies of the managers are tabulated systemmatically. The 28 tables provide interesting details, but very few broad generalizations emerge from them.

All the American companies examined operating in Canada have of necessity adapted their operations to take into consideration the different situations and circumstances found in Ontario and Quebec, in particular. The method cho- sen by the author to ascertain these differences, as stated by the author, was \& questioning executives who have served in that organization in at least two cultures, and by asking the same questions to operating personnel in the same corporation, but employed in different cultural settings $\gg$. (p. 120)

Some general observations are as follows :

«... More problems were encountered with French Canadian operations than with those in English Canada, problems growing out of bilingualism ... and a greater difference (in) ... the culture of French Canada...» (p. 121)

Labor Institutions : «Labor unions in Canada are more interested in social change and participation in management than are their counterparts or even their affiliates, in the U.S.» (p. 122)

Government : «As far as business operations are concerned, Canadian managers are more concerned with government at the provincial level than they are with the federal government; U.S. managers ... are more concerned with federal rather than state government. (p. 123)

« In English and French Canada the pace of business if slower, the sense of urgency less than in the U.S. Canadians also show a greater interest in time off...

« As managers, French Canadians are seen as more autocratic... Mobility of French Canadian personnel is a serious problem for managers of companies with operations in both Quebec and other parts of Canada. $\gg$ (p. 125)

$\operatorname{Re}:$ Modification of corporate policy and practice to deal with cultural differences : «U.S. corporate policy requires greater modification before it can be applied both in English and French Canada than that required before it can be put into effect in different parts of the U.S. ... Problems ... . involve decisions about the degree to which corporate policy can be modified to fit the local situation, while at the same time retaining a degree of uniformity between its operations in different parts of the country $\gg$. (pp. 126-127) 
With supervisory mobility what it is today, this study illustrates in a specific way, the general problems managers must face when transfers become a way of corporate life.

\section{Joan SICHEL}

\section{Automation: Threat or Promise ? - Im-} pact and Implications in Australia, by G.W. Ford, ed., Law Book Co. Ltd., 1969, 214 pp.

Ce volume est un compte-rendu d'un symposium tenu par l'Association pour l'avancement des sciences de l'Australie et de la Nouvelle-Zélande. L'année exacte n'est pas mentionnée mais il semblerait que le sous-comité sur l'automation ait commencé son travail au cours de l'année 1966.

En choisissant un sujet aussi vaste, il est facile de comprendre pourquoi on a tenté à la fois de définir le phénomène de l'automation et de décrire ses implications socio-économiques, au risque de demeurer dans des généralités.

Les exposés, pour la plupart, abordent des points très discutés tels que les effets de l'automation sur l'éducation, la formation professionnelle, l'emploi, le syndicalisme, le climat des relations patronales-ouvrières, etc. En plus de décrire les effets, les conférenciers indiquent les différentes avenues que des recherches subséquentes pourraient emprunter.

Ces exposés théoriques sont suivis de quelques études de cas décrivant avec assez de précision les étapes de l'introduction d'appareils automatiques dans le domaine des communications et de la distribution du gaz et de l'électricité.

Les observations et les réflexions des conférenciers sur les implications de l'automation rejoignent celles des chercheurs nord-américains. Ceci nous amène à conclure que les effets de l'automation demeurent passablement similaires quoique leur intensité varie lorsqu'on passe d'un pays industrialisé à un autre.

C'est un volume qui se lit facilement puisque les exposés sont regroupés sous le thème qui leur est commun. Chaque thème abordé constitue une partie avec des liens établis par des conférenciers et une conclusion rédigée par $M$. Davenport, vice-président de l'Association.

\section{Laurent BELANGER}

Labor Relations and Collective Bargaining, Text and Case, by Max G. Wortman Jr. and George C. Witteried, Boston, Allyn and Bacon, 1969, 388 pp.

Ce livre constitue un instrument pédagogique de première main qui s'inscrit dans les perspectives les plus récentes de l'enseignement en relations industrielles. Il présente, en plus d'un cadre de référence qu'on aurait souhaité un peu plus élaboré, une sélection importante de cas vécus illustrant les différents problèmes qui résultent de la négociation et de l'application de la convention collective.

L'étude et la discussion de ces cas par les étudiants et les professeurs devient un complément intéressant aux enseignements théoriques sur la convention collective en ce qu'ils permettent le contact avec un certain nombre de situations vécues par les parties elles-mêmes.

Il importe de souligner que les cas choisis couvrent une grande variété de problèmes. D'une part, des problèmes que l'on pourrait qualifier de «traditionnels $\gg$ tels que la détermination de l'unité de négociation, la procédure des griefs, les heures de travail, les salaires, etc. D'autre part, on fait place, et c'est là l'un des mérites de l'ouvrage, à des situations qui naissent du développement industriel dans une économie moderne; citons notamment les avantages sociaux, les mesures de protection des salariés en cas de changements technologiques, la question des sous-contrats, etc.

Dans la présentation des «cas», on essaie de reconstituer le mieux possible le contexte dans lequel ils se sont produits. De plus, pour faciliter la discussion, les auteurs proposent une série de questions pertinentes à chaque problème.

S'il s'agit d'un ouvrage à caractère plutôt pratique que théorique, il serait erroné d'affirmer qu'il a été conçu sans référence à des réflexions théoriques. 